\title{
Akdeniz Ekolojik Şartlarındaki Kahramanmaraş’ta Farklı Olgunlaşma Dönemlerinde Biçmenin Bazı Fiğ (Vicia sp.) Türlerinin I. Ot Verimi ve Kalitesi Üzerine Etkilerinin Belirlenmesi*
}

\section{Determination of Yield and Hay Quality of Some Vetch (Vicia sp.) Species Cutted at Different Times at Kahramanmaraş under Mediterranean Ecological Conditions}

\section{Muhsin OVA ${ }^{1}$}

\section{Ömer Süha USLU2 ${ }^{* *}$}

1,2 Kahramanmaraş Sütçü İmam Üniversitesi, Fen Bilimleri Enstitüsü, Tarla Bitkileri Anabilim Dalı, Kahramanmaraş

**Sorumlu yazar: suhauslu@ksu.edu.tr

0000-0001-5955-003X

0000-0003-0858-0305

*Bu makale, ilk yazarın yüksek lisans tezinin bir kısmından özetlenmiştir.

Destekleyen Kurum : Kahramanmaraş Sütçü İmam Üniversitesi Bilimsel Araştırma Projeleri Koordinasyon Birimi

Proje Numarası : 2018/3-15 YLS

Gönderilme Tarihi:

9 Ekim 2020

Kabul Tarihi . $\quad 25$ Kasım 2020

\section{ÖZET}

$\mathrm{Bu}$ araştırma, farklı olgunlaşma dönemlerinde biçilen bazı fiğ (Vicia sp.) türlerinin verim ve ot kalitelerinin belirlenmesi amacıyla yürütülmüş̧ür. Araştırma 2017-2018 yetiştirme sezonunda Kahramanmaraş Sütçü İmam Üniversitesi, Ziraat Fakültesi, Tarla Bitkileri Bölümü deneme alanında tesadüf blokları deneme desenine göre 3 tekerrürlü olarak yürütülmüş̧ür. Araştırma materyali olarak fiğ (Vicia sp.) türü (yaygın fiğ-Zemheri 08, macar fiği-Kansur ve tüylü fiğSelçuklu 2002) kullanılmıştır. Denemede 4 farklı gelişme döneminde (çiçeklenme başlangıcı, \%50 çiçeklenme, tam çiçeklenme ve bakla olum dönemi) hasat edilen fiğin verimi ve ot kalitesi incelenerek en uygun hasat zamanının belirlenmesi amaçlanmıştır. Araştırma sonuçlarına göre, en yüksek kuru ot verimi $887.47 \mathrm{~kg} / \mathrm{da}$ ile Selçuklu 2002, ham protein oran $1 \% 21$ ile Kansur, ham protein verimi $162.6 \mathrm{~kg} / \mathrm{da}$ ile Selçuklu 2002, ham kül oranı \%15.79 ile Zemheri 08, NDF oranı \%57 ile Kansur, ADF oran1 \%39 ile Selçuklu 2002 ve nispi yem değeri (NYD) 145.10 ile Zemheri 08 çeşitlerinden elde edilmiştir. Akdeniz ekolojik şartlarındaki Kahramanmaraş'ta nispi yem değeri açısından ele alındığında en uygun fiğ türünün Zemheri 08 çeşidi 
(yaygın fiğ) olduğu ve çiçeklenme başlangıcında biçilmesinin uygun olacağı belirlenmiştir.

Anahtar Kelimeler: Biçim zamanı, fiğ, ham protein oran1, NDF ve ADF oran1, Vicia sp., yem kalitesi

\section{ABSTRACT}

This study was carried out in order to determine hay yield and hay quality of some vetch (Vicia sp.) varieties cutted at different times. The research was conducted in 2017-2018 growing season in Kahramanmaraş Sütçü İmam University, Faculty of Agriculture and Department of Field Crops with 3 replications according to randomized complete block design in order to determine. Common vetch-Zemheri 08 , hungarian vetch-Kansur and hairy vetch-Selçuklu 2002 were used as research material. The aim of this study was to determine the most suitable harvest time by considering the quality and yield of the vetch harvested in 4 different development periods (flowering period, $50 \%$ flowering period, full flowering period and pod maturing period). According to the results of the research, the highest dry herbage yield as $887.47 \mathrm{~kg} / \mathrm{da}$ in Selçuk 2002, crude protein rate $21 \%$ in Kansur, crude protein yield as $162.6 \mathrm{~kg} /$ da in Seçuklu 2002, crude ash rate as 15.79 in Zemheri 08, NDF rate as 57\% in Kansur, ADF rate as 39\% Selçuklu 2002 and relative feed value (RFV) as $145.10 \%$ in Zemheri 08 were determined. When considered in terms of relative feed value, it was determined that the most suitable vetch species was Zemheri 08 variety (common vetch) and it would be suitable to cut at the beginning of flowering at Kahramanmaraş under Mediterranean ecological conditions.
Key words: Crude protein, cutting time, feed quality, NDF and ADF, vetch, Vicia sp.

\section{GİRIŞ̧}

Ülkemizde hayvancıllğı̆n gelişmesi, hayvan besleme maliyetlerinin düşmesine ve kaliteli kaba yem üretiminin artmasına bağlıdır. Kaliteli kaba yem için yem bitkileri yetiştiriciliğinin desteklenmesi ve geliştirilmesi lazımdır. Yem bitkileri arasında fiğ türleri kaliteli bir kaba yem kaynă̆ıdır. Fi ̌̆g, baklagiller familyasından yaş ve kuru ot, dane ve silaj olarak değerlendirilebilen tek yıllık serin mevsim yem bitkisidir. Mineral madde, protein ve vitamin bakımından oldukça zengindir. Havadaki serbest azotu toprağa fikse ederek toprağın azot içeriğini artıırı. İyi bir yeşil gübre olarak toprağı organik madde yönünden zenginleştirir. İklim istekleri yönünden en belirgin özelliği kış soğuklarına ve kuraklığa karşı dayanıklı olmasıdır.

Hasat zamanına bağlı olgunluk yem bitkilerinin çok önemli bir kalite faktörüdür. Olgunlaşma ile yemlerin kalitesi düşmektedir. Bitkinin hasat dönemi kaliteyi etkileyen çok önemli bir faktördür. Bitkideki ileri düzey olgunlaşma NDF ve ADF oranındaki artışa bağlı olarak sindirimi zorlaştırmaktadır (Van Soest, 1994; Wilson ve ark., 1991; Morrison, 1980). Biçimzamanıileilgili yapılan çalışmalarda baklagillerin olgunlaşma ile selüloz ve hemiselüloz miktarında artış, protein miktarında düşüş olduğu, çiçeklenme başlangıcında \%19 olan protein miktarının tam çiçeklenme döneminde \%30'a, biçim zamanında meydana gelen gecikmenin NDF ve ADF miktarını artırdığ 1 ifade edilmiştir (Sarıçiçek ve ark., 1996; Özen, 1999; Cassida ve ark., 2000). 
Yine kışın yetişen buğdaygil yem bitkilerinin başaklanma başında sindirilme miktarı \% 65,7 'den çiçeklenme dönemi sonunda $\% 51,5$ 'e düştüğü ve bitkideki olgunluk ile birlikte yem tüketiminin de azaldığg tespit edilmiştir (Budak ve Budak, 2014).

$\mathrm{Bu}$ çalışma, Doğu Akdeniz Bölgesinde yer alan Kahramanmaraş'ta farklı olgunlaşma dönemlerinde biçilen fiğ türlerinde, biçim zamanının kuru ot verimi ve kalitesi üzerine etkilerini saptamak amacıyla yürütülmüştür.

\section{MATERYAL ve YÖNTEM}

Çalışma 2017-2018 kış üretim sezonunda, Kahramanmaraş Sütçü İmam Üniversitesi Ziraat Fakültesi Tarla Bitkileri Bölümüne ait araştırma sahasında gerçekleştirilmiştir. Akdeniz bölgesinde, $37^{\circ} 35^{\prime} 40.86^{\prime \prime}$ kuzey enlem ve $36^{\circ} 48^{\prime} 47.51^{\prime \prime}$ doğu boylam dereceleri arasında yer alan deneme alanı \% 3-5 eğime sahip olup deniz seviyesinden yüksekliği 487 m'dir. Yörede Akdeniz iklimi hâkim olup, gece ve gündüz arasındaki sıcaklık farkı az, kışları ılık ve yağışlı, yazları ise sıcak ve kurak geçmektedir. Kahramanmaraş'ta araştırma sezonunda toplam yağış miktarı $523.5 \mathrm{~mm}$, sicaklık ortalaması 14.7 ${ }^{\circ} \mathrm{C}$ ve ortalama nispi nem \% 59.97 olarak, aynı dönemde uzun yıllar ortalaması toplam yağış miktarı $650.8 \mathrm{~mm}$, sicaklık ortalaması 12.6 ve ortalama nispi yem değeri \% 63.04 olarak gerçekleşmiştir (Anonim, 2018a). Deneme alanına ait 0-30 $\mathrm{cm}$ derinlikten alınan toprak numunesi yapılan analiz neticesinde; ağır bünyeli (\% 85.8 killi), nötr ( $\mathrm{pH} 7.28)$, hafif tuzlu (\% 0.3), çok az kireçli (\% 1), organik madde bakımından orta (\% 2.08), potasyum oranı yüksek (266.8 $\mathrm{mg} / \mathrm{kg})$ ve fosfor oranı az $(10.46 \mathrm{mg} / \mathrm{kg})$ olarak belirlenmiştir (Anonim, 2018b). Tarla hazırlı̆ğ için pulluk ile derin sürüm yapılmış daha sonra kültivatör ve tapan çekilmiştir. Deneme 27 Kasım 2017 tarihinde tesadüf blokları deneme desenine göre 3 tekerrürlü olarak kurulmuştur. Ekim 20 $\mathrm{cm}$ sıra aralığında $3 \mathrm{~m}$ uzunluğundaki altı sıraya elle yapılmıştır. Her bir parselin alanı 6 sıra $\mathrm{x}$ $0.20 \mathrm{~m}=1.2 \mathrm{~m}, 3 \mathrm{~m} \times 1.2 \mathrm{~m}=3.6 \mathrm{~m}^{2}$ olarak hesaplanmıştır. Çeşitlerin bin tane ağırlıkları hesap edilerek, parsellerde metrekareye 250 adet tohum gelecek şekilde tohum kullanılmıştır. Ekimle beraber $5 \mathrm{~kg} / \mathrm{da}$ saf azot ve fosfor olacak şekilde 20.20.0 kompoze gübre ile taban gübrelemesi yapılmıştır. Deneme alanında sulama yapılmamıştır. Yabancı ot mücadelesi elle yapılmıştır.

Araştırma konusu iki farklı uygulamadan oluşmaktadır. $\mathrm{Bu}$ faktörlerin ilki olgunlaşma dönemi, ikincisi ise türlerdir. İlk deneme faktörü olan olgunlaşma dönemi; çiçeklenme başlangıcı (ÇB), \%50 çiçeklenme dönemi (\%50 ÇD), tam çiçeklenme dönemi (TÇD) ve bakla olum dönemi (BOD) olmak üzere dört farklı dönemden oluşmaktadır. Diğer deneme faktörü olan tür kapsamında; macar fiğinin Kansur (Vicia pannonica Crantz.), tüylü fiğin Selçuklu 2002 (Vicia villosa Roth.) ve yaygın fiğin Zemheri 08 (Vicia sativa L.) çeşitleri kullanılmıştır. Hasat işlemi, parsel yanlarından birer adet sıra, parsel alt ve üst taraflarından $50 \mathrm{~cm}$ kenar tesiri olarak atıldıktan sonra yapılmıştır. Hasat edilen parsel alanı $1.6 \mathrm{~m} 2$ olmuştur.

İncelenen özellikler; Kaçar (1972), Sheaffer vd. (1995), Parlak (2005), Kutlu (2008), Ünal vd.. 
(2011), Anonim (2019) tarafindan tarif edilen yöntemlere göre yapılmıştır.

Her parselden hasat edilen yeşil otlar tartıldıktan sonra, içerisinden rasgele alınan 0.5 kg'lık yeşil ot örnekleri kese kağıtlarına konularak, kurutma dolabında 48 saat $70{ }^{\circ} \mathrm{C}^{\prime}$ de kurutulmuştur. Kurutma dolabından çıkarılan örnekler 24 saat oda sicaklığında bekletildikten sonra kuru ot ağırlığını belirlemek amacıyla $5 \mathrm{~g}$ hassasiyetli elektronik terazide tartılmıştır. Elde edilen kuru ot değerlerinden dekara kuru ot verimleri $\mathrm{kg} /$ da olarak hesap edilmiştir. Kurutulmuş bitki örnekleri öğütülerek $1 \mathrm{~mm}$ elekten geçirilmiş ve analize hazır hale getirilmiştir. Ögütülen ot örneklerinde Kjeldahl yöntemi ile azot tayini analizi yapılmıştır. Ölçülen azot yüzdesi değerleri daha sonra 6.25 katsayısı ile çarpılmış, her örneğe ait ham protein içeriği belirlenmiştir. Parselin ham protein oranı parsele ait kuru ot verimi ile çarpılmış ve ham protein verimi belirlenmiş daha sonra gerekli dönüşümler yapılmış ham protein verimi $\mathrm{kg} /$ dekar cinsinden hesaplanmıştır. Ham kül oranı belirlenmesinde

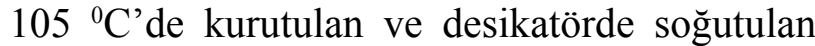
bitki numunelerinden temin edilen 3'er gramlık örnekler, porselen krozeye yerleştirilerek 550 ${ }^{0} \mathrm{C}$ 'de 3 saat süreyle yakılmıştır. Elde edilen kül yakılan örneğe oranlanarak ham kül oranı hesaplanmıştır.

Nötr ortamda çözünmeyen lif (NDF) ve asitli ortamda çözünmeyen lif (ADF) içerikleri ANKOM filtre torbası tekniği kullanılarak ANKOM A220 lif analiz cihazı (ANKOM Teknoloji, Fairport, NY) vasitasıyla belirlenmiştir. Sindirilebilir kuru madde (SKM) değeri, kuru madde tüketimi (KMT) değeri ve nispi yem değeri (NYD) NDF ve ADF analiz sonuçları değerlendirilerek aşağıdaki formüller ile hesaplanmıştır.

$\operatorname{SKM}(\%)=88.9-(0.779 \times \%$ ADF $)$

$\operatorname{KMT}(\%)=120 / \% \mathrm{NDF}$

$\mathrm{NYD}=(\mathrm{SKM} \times \mathrm{KMT}) / 1.29$

Araştırma sonucunda elde edilen veriler tesadüf bloklarında faktöriyel düzenleme deneme desenine göre SAS V.9.3 (SAS, 2013) programında varyans analizine tabi tutulmuştur. Varyans analiz sonuçlarına göre istatistiksel olarak önemli bulunan özelliklere ilişkin ortalamalar arasındaki farklılıklar LSD testi ile karşılaştırılmıştır.

\section{BULGULAR ve TARTIŞMA}

\subsection{Kuru Ot Verimi (kg/da)}

Farklı olgunlaşma dönemlerinde biçilen fiğ türlerinin kuru ot verimleri arasındaki fark istatistiki olarak önemlidir. Yine türler arasındaki farklar da önemli, tür x olgunlaşma dönemi interaksiyonu arasındaki farklar önemsiz bulunmuştur. En yüksek kuru ot verimi ortalaması Selçuklu 2002 çeşidinde 784.42 $\mathrm{kg} / \mathrm{da}$, en düşük kuru ot verimi ortalaması ise Zemheri 08 çeşidinde $515.89 \mathrm{~kg} / \mathrm{da}$ olarak elde edilmiştir (Çizelge 1). Olgunlaşma dönemlerine ait kuru ot verimi ortalamaları bakıldığında ise \%50 çiçeklenme, tam çiçeklenme ve bakla olum dönmelerinde elde edilen kuru ot değerleri aynı grupta yer almış, en yüksek kuru ot verimi bakla olum döneminde $(756.40 \mathrm{~kg} / \mathrm{da})$, en düşük kuru ot verimi ise çiçeklenme başlangıcında yapılan ölçümde $(480.58 \mathrm{~kg} / \mathrm{da})$ elde edilmiştir 
(Çizelge 1). Aynı istatistiki grupta yer alan diğer biçim zamanları ile çiçeklenme başlangıcı kıyaslandığında kuru ot verimi \% $140-157$ oranında bir artış göstermiştir. Olgunlaşma dönemi ve tür interaksiyonu ortalamaları yönünden yapılan değerlendirme istatistiksel olarak önemsiz çıkmıştır.

Bulgularımız daha önce aynı konuda çalışma yapan araştırmacıların sonuçlarıyla karşılaştırıldığında, Bağcı (2010)'nın Orta Anadolu Bölgesinde (323-353 kg/da), Kara (2013)'nın Erzurum koşullarında macar fiğinde (216.1-274.2 kg/da), Güzeloğulları ve Albayrak (2016)'ın Isparta koşullarında tüylü fiğde (440.89 kg/da) elde edilen bulgularından yüksek, Aksoy vd. (2010)'nın Van ilinde (363-654 kg/ da), Erdoğdu vd. (2016)'nın Eskişehir'de macar fiğinde (633 kg/da), Turna ve Ertuş (2017)'un Van'da (510.28 kg/da), Hashalıcı vd. (2017)'nın da), Kavut ve Geren (2018)'in İzmir'de tüylü fiğde $(718 \mathrm{~kg} / \mathrm{da})$ tespit ettikleri bulgulara yakın, Budak vd. (1997)'nın Kayseri'de (963 kg/da) ve Akdeniz vd. (1999)'nın Van ekolojik şartlarında elde ettikleri (1481 ve $1450 \mathrm{~kg} / \mathrm{da}$ ) bulgulardan düşük bulunmuştur.

\subsection{Ham Kül Oranı (\%)}

Farklı olgunlaşma dönemlerinde biçilen fiğ türlerinin ham kül oranları arasındaki fark istatistiki olarak önemli bulunmuştur. En yüksek ham kül oranı ortalaması Zemheri 08 çeşidinde \% 14.62, en düşük ham kül oranı ortalaması ise Kansur çeşidinde \% 12.85 olarak hesaplanmıştır. Olgunlaşma dönemleri arasındaki farklar önemsiz olmakla birlikte en yüksek ham kül oranı çiçeklenme başlangıcında elde edilen otta, en düşük ham kül oranı ise $\% 50$ çiçeklenme döneminde yapılan biçimde elde edilmiştir (Çizelge 1).

Kayseri ilinde macar fiğinde $(393.5-782.3 \mathrm{~kg} /$

Çizelge 1. Farklı olgunlaşma dönemlerinde biçilen fiğ türlerinin kuru ot verimi ve ham kül oranı ortalamaları ve oluşan gruplar

Kuru Ot Verimi (kg/da) Ham Kül Oranı (\%)

\begin{tabular}{llllccccc}
\hline & Zemheri 08 & Kansur & Selçuklu & Ort. & Zemheri 08 & Kansur & Selçuklu & Ort. \\
\hline ÇB & 378.63 & 469.63 & 593.43 & $480.58^{\mathrm{B}+}$ & 15.79 & 13.30 & 14.67 & 14.59 \\
$\% 50$ ÇD & 447.97 & 693.77 & 887.47 & $676.40^{\mathrm{A}}$ & 13.83 & 10.00 & 15.35 & 13.06 \\
& & & & & & & & \\
TÇD & 469.53 & 802.97 & 803.93 & $692.14^{\mathrm{A}}$ & 14.43 & 14.64 & 13.45 & 14.18 \\
BOD & 767.40 & 648.93 & 852.83 & $756.40^{\mathrm{A}}$ & 14.42 & 13.45 & 14.21 & 14.02 \\
\hline Ort. & $515.89^{\mathrm{C}}$ & $653.83^{\mathrm{B}}$ & $784.42^{\mathrm{A}}$ & 651.38 & $14.62^{\mathrm{A}^{*}}$ & $12.85^{\mathrm{B}}$ & $14.42^{\mathrm{A}}$ & 13.96 \\
\hline VK & 23.57 & & & & $\mathrm{VK}$ & 12.67 & &
\end{tabular}

${ }^{+}$) Aynı sütun içerisinde benzer harf ile gösterilen ortalamalar LSD testine göre $\mathrm{P} \leq 0.01$ hata sınırları içerisinde birbirinden istatistiksel olarak farksızdır. *) Aynı satır içerisinde benzer harf ile gösterilen ortalamalar LSD testine göre $\mathrm{P} \leq 0.01$ hata sınırları içerisinde birbirinden istatistiksel olarak farksızdır. 
Bulgularımız, Canpolat ve Karaman (2009)'1n Bursa'da (\% 8.05), Kuşvuran vd. (2014)'nın Çankırı'da (\% 9.4) ve Hashalıcı vd. (2017)'nın Kayseri'de (\% 8.95-11.83) elde ettiği sonuçlarla kısmen benzerlik göstermektedir.

\subsection{Ham Protein Oranı (\%)}

Çizelge 2' de görüldüğü gibi türlere ve olgunlaşma dönemlerine ait ortalama değerler arasındaki farkların istatistiksel olarak çok önemli ve tür $\mathrm{x}$ olgunlaşma dönemi interaksiyonuna ait ortalama değerler arasındaki farkların istatistiksel olarak önemsiz olduğu anlaşılmaktadır. En yüksek ham protein oranı Kansur çeşidinde \% 19.25, en düşük ham protein oranı ise aynı grupta yer alan ve aynı sonucun elde edildiği Zemheri 08 ve Selçuklu 2002 çeşitlerinde \% 18.50 olarak bulunmuştur. Olgunlaşma dönemlerine göre en yüksek ham protein oranı çiçeklenme başlangıcı döneminde (\% 19.68), en düşük ham protein oranı ise tam çiçeklenme döneminde yapılan biçimde (\% 18.00) elde edilmiştir (Çizelge 2). Olgunlaşma dönemi ve tür interaksiyonu yapılan istatistiki analize göre önemsiz çıkmıştır.

Ham protein oranı bakımından elde edilen bulgular Çaçan vd. (2017)'nın Bingöl'de (\%14.220.0) elde ettiği bulgularla kısmen uyumlu veya yüksek bulunurken, Edirne Uzunköprü İlçesi ekolojik şartlarında Dündar (2010)'ın \% 22.5629.08 arasında elde ettiği sonuçlardan düşük çıkmıştır.

\subsection{Ham Protein Verimi (kg/da)}

Çizelge 2'de görüldüğü gibi türlere ve olgunlaşma dönemlerine ait ortalama değerler arasındaki farkların istatistiksel olarak çok önemli ve tür $\mathrm{x}$ olgunlaşma dönemi interaksiyonuna ait ortalama değerler arasındaki farkların istatistiksel olarak önemsiz olduğu anlaşılmaktadır. En yüksek ham protein verimi Selçuklu 2002 çeşidinde (146.9 $\mathrm{kg} / \mathrm{da})$, en düşük ham protein oranı ise Zemheri

Çizelge 2. Farklı olgunlaşma dönemlerinde biçilen fiğ türlerinin ham protein oranı ve ham protein verimi ortalamaları ve oluşan gruplar

\begin{tabular}{|c|c|c|c|c|c|c|c|c|}
\hline & Zemheri 08 & Kansur & Selçuklu & Ort. & Zemheri 08 & Kansur & Selçuklu & Ort. \\
\hline ÇB & 18.00 & 21.00 & 20.00 & $19.68^{\mathrm{A}+}$ & 67.20 & 97.60 & 120.80 & $95.2^{\mathrm{B}-}$ \\
\hline \%50 ÇD & 20.00 & 19.00 & 18.00 & $19.00^{\mathrm{B}}$ & 90.60 & 132.73 & 162.63 & $128.6^{A}$ \\
\hline TÇD & 17.00 & 19.00 & 18.00 & $18.00^{\mathrm{D}}$ & 80.70 & 152.16 & 147.30 & $126.7^{\mathrm{A}}$ \\
\hline BOD & 19.00 & 18.00 & 18.00 & $18.33^{\mathrm{C}}$ & 144.50 & 114.70 & 157.00 & $138.7^{\mathrm{A}}$ \\
\hline Ort. & $18.50^{\mathrm{B}^{*}}$ & $19.25^{\mathrm{A}}$ & $18.50^{\mathrm{B}}$ & 18.75 & $95.75^{\mathrm{B}^{*}}$ & $124.3^{\mathrm{A}}$ & $146.9^{\mathrm{A}}$ & 122.3 \\
\hline
\end{tabular}

${ }^{+}$) Aynı sütun içerisinde benzer harf ile gösterilen ortalamalar LSD testine göre $\mathrm{P} \leq 0.05$ hata sinırları içerisinde birbirinden istatistiksel olarak farksızdır. *) Aynı satır içerisinde benzer harf ile gösterilen ortalamalar LSD testine göre $\mathrm{P} \leq 0.05$ hata sınırları içerisinde birbirinden istatistiksel olarak farksızdır. 
08 çeşidinde $(95.75 \mathrm{~kg} / \mathrm{da})$ elde edilmiştir. \%50 çiçeklenme, tam çiçeklenme ve bakla olum dönemlerinde elde edilen ham protein verimi ortalamaları istatistiksel olarak aynı grupta yer alırken (sırası ile 128.6, 126.7 ve $138.7 \mathrm{~kg} / \mathrm{da}$ ), en düşük ham protein verimi çiçeklenme başlangıcı döneminde yapılan biçimde $(95.2 \mathrm{~kg} / \mathrm{da})$ elde edilmiştir (Çizelge 2). Olgunlaşma dönemi ve tür interaksiyonu yapılan değerlendirmeye göre istatistiksel olarak önemsiz çıkmıştır.

Bulgularımız, Çaçan vd. (2017)'nın Bingöl'de (21.2-37.3 kg/da), Ünal vd. (2011)'nın Ankara'da $(16.9-22.8 \mathrm{~kg} / \mathrm{da})$ yaptıkları çalışmalarda elde ettikleri bulgulardan yüksek, Aksoy vd. (2010)'nın Van'da (42.90-89.57 kg/da) elde ettiği bulgulara kısmen yakın, Hashalıcı vd. (2017)'nın Kayseri'de (70.8-130.1 kg/da) elde ettiği bulgular ile uyum içerisindedir.

\subsection{Nötr Deterjan Lif (NDF) Oranı (\%)}

Çizelge 3'teki ortalamalar incelendiğinde en yüksek NDF oranı Kansur çeşidinde \% 50.50, en düşük NDF oranı ise Zemheri 08 çeşidinde \% 44.00 olarak bulunmuştur. Yine en yüksek NDF oranı aynı değerlerin elde edildiği ve aynı grupta yer alan \%50 çiçeklenme ve tam çiçeklenme döneminde \% 50.00, en düşük NDF oranı ise çiçeklenme başlangıcında yapılan biçimde \% 44.67 olarak ölçülmüştür (Çizelge 3). İstatistiki olarak önemli bulunan olgunlaşma dönemi ve tür interaksiyonu yönünden yapılan değerlendirmeye göre en yüksek NDF oranı Kansur çeşidinde tam çiçeklenme döneminde (\% 57.00), en düşük NDF oranı ise Zemheri 08 ve Selçuklu 2002 çeşitlerinde çiçeklenme başlangıcında (\% 42.00) elde edilmiştir (Çizelge 3).

Türk vd. (2009) Isparta' da tüylü fiğde olgunlaşma

Çizelge 3. Farklı olgunlaşma dönemlerinde biçilen fiğ türlerinin NDF ve ADF Oranı ortalamaları ve oluşan gruplar
NDF Oranı (\%)
ADF Oranı (\%)

\begin{tabular}{llllcllll}
\hline & Zemheri 08 & Kansur & Selçuklu & Ort. & Zemheri 08 & Kansur & Selçuklu & Ort. \\
\hline ÇB & $42.00^{\mathrm{b}}$ & $50.00^{\mathrm{ab}}$ & $42.00^{\mathrm{b}}$ & $44.67^{\mathrm{C}+}$ & 30.00 & 33.00 & 34.00 & $32.33^{\mathrm{C}+}$ \\
$\% 50 \mathrm{ÇD}$ & $46.00^{\mathrm{ab}}$ & $50.00^{\mathrm{ab}}$ & $54.00^{\mathrm{ab}}$ & $50.00^{\mathrm{A}}$ & 34.00 & 35.00 & 39.00 & $36.00^{\mathrm{A}}$ \\
& & & & & & & & \\
TÇD & $47.00^{\mathrm{ab}}$ & $57.00^{\mathrm{a}}$ & $46.00^{\mathrm{ab}}$ & $50.00^{\mathrm{A}}$ & 33.00 & 37.00 & 35.00 & $35.00^{\mathrm{AB}}$ \\
BOD & $44.00^{\mathrm{ab}}$ & $45.00^{\mathrm{ab}}$ & $50.00^{\mathrm{ab}}$ & $46.33^{\mathrm{B}}$ & 30.00 & 33.00 & 37.00 & $33.33^{\mathrm{BC}}$ \\
\hline Ort. & $44.75^{\mathrm{C}^{*}}$ & $50.50^{\mathrm{A}}$ & $48.00^{\mathrm{B}}$ & 47.75 & $31.75^{\mathrm{C}^{*}}$ & $34.50^{\mathrm{B}}$ & $36.25^{\mathrm{A}}$ & 34.16 \\
\hline
\end{tabular}

VK $\quad 3.23$

VK5.76

${ }^{+}$) Aynı sütun içerisinde benzer harf ile gösterilen ortalamalar LSD testine göre $\mathrm{P} \leq 0.01$ hata sınırları içerisinde birbirinden istatistiksel olarak farksızdır. *) Aynı satır içerisinde benzer harf ile gösterilen ortalamalar LSD testine göre $\mathrm{P} \leq 0.01$ hata sınırları içerisinde birbirinden istatistiksel olarak farksızdır. ${ }^{1}$ ) Benzer harf ile gösterilen interaksiyon ortalamaları LSD testine göre $\mathrm{P} \leq 0.01$ hata sınırları içerisinde birbirinden istatistiksel olarak farksızdır. 
dönemine bağlı olarak çiçeklenme başlangıcında $\% 24.53$ olanNDF oranınınbakla olum döneminde \% 30.06'ya düştüğünü tespit etmiş̧ir. Albayrak vd. (2009)'nın Isparta'da tüylü fiğ ile yaptıkları çalışmada ise çiçeklenme başlangıcında \% 25.02 olan NDF oranının tam çiçeklenme döneminde $\% 30.62$, bakla olum döneminde ise \% 33.17 olduğu bildirilmiştir. Sürmen vd. (2011) Samsun'da yaygın fiğde olgunlaşma dönemine bağlı olarak NDF oranlarının \% 30.35-36.43 arasında değiştiğini bulmuşlardır. Macar fiği ile ilgili yapılan çalışmalarda NDF oranlarını Kara (2013) Erzurum ilinde \% 38.30-45.00 arasında tespit etmiştir. Bulgularımız araştırıcıların elde ettiği sonuçlardan yüksek çıkarken, Hashalıcı vd. (2017)'nın Kayseri'de (\% 39.05-46.79) ve Yılmaz vd. (1996)'nın Doğu Akdeniz ekolojik koşullarında (\% 50.47) elde ettikleri sonuçlar ile benzerlik göstermektedir.

\subsection{Asit Deterjan Lif (ADF) Oranı (\%)}

En yüksek ADF oranı Selçuklu 2002 çeşidinde $\%$ 36.25, en düşük ADF oranı ise Zemheri 08 çeşidinde \% 31.75 olarak bulunmuştur. Yine en yüksek ADF oranı $\% 50$ çiçeklenme döneminde $\% 36.00$, en düşük $\mathrm{ADF}$ oranı ise çiçeklenme başlangıcında yapılan biçimde \% 32.33 olarak elde edilmiştir (Çizelge 3).

Daha önce fiğde ADF oranını belirlemek için yapılan çalışmalarda, Rebole ve vd. (2004)'nın İspanyanın Kastilya Ovasında yaygın fiğde çiçeklenme döneminde ADF oranını \% 26.4 arasında belirlemişlerdir. Türk ve vd. (2009) Isparta'da tüylü fiğde çiçeklenme başlangıcında \% 22.64 olarak elde ettikleri ADF oranının bakla olum döneminde \% 34.85 değerine yükseldiğini bildirmişlerdir. Sürmen ve vd. (2011)'nın Samsun'da yaygın fiğde yaptı̆̆ çalışmada, olgunlaşma dönemine bağlı olarak ADF oranlarının \% 24.6-27.89 arasında, Kavut vd. (2014) Bornova'da yaygın fiğde yaptıkları çalışmada \% 25.77-33.65 arasında değiştiğini bildirilmiştir. Bulgularımız araştırıcıların bulguları ile kısmen benzerlik göstermektedir. ADF oranları arasındaki farklılıkların, deneme materyali olarak kullanılan fiğ çeşitlerindeki değişiklik ve denemenin yapıldığ 1 yerin ekolojik şartlarındaki farklılıklardan kaynaklandığ söylenebilir.

\subsection{Sindirilebilir Kuru Madde Değeri (\%)}

Çizelge 4'te görüldüğü gibi tür ve olgunlaşma dönemine ait değerlerin istatistiksel olarak önemli, tür x olgunlaşma dönemi interaksiyonuna ait değerlerin istatistiksel olarak önemsiz olduğu anlaşılmaktadır. En yüksek sindirilebilir kuru madde değeri Zemheri 08 çeşidinde (\% 64.25), en düşük sindirilebilir kuru madde değeri ise Selçuklu 2002 çeşidinde (\% 60.66) elde edilmiştir. Yine en yüksek sindirilebilir kuru madde değeri çiçeklenme başlangıcında (\% 63.67), en düşük sindirilebilir kuru madde değeri ise \%50 çiçeklenme döneminde (\% 60.89) elde edilmiştir (Çizelge 4).

Bulgularımız; Mutlu (2012)'nun Haymanaİkizce ekolojik koşullarında (\% 56.57), Güzeloğulları ve Albayrak (2016)'ın Isparta ekolojik koşullarında (\% 62.15), Kavut ve Geren (2018)'in Bornova İzmir ekolojik koşullarında (\% 66.23) elde ettikleri bulgularla benzerlik göstermektedir. 


\subsection{Kuru Madde Alım Değeri (\%)}

Çizelge 4'te görüldüğü gibi tür ve olgunlaşma dönemine ait değerlerin istatistiksel olarak önemli farklılık gösterdiği, tür x olgunlaşma dönemine ait interaksiyonun ise önemli bulunmadığ 1 anlaşılmaktadır. En yüksek kuru madde alım değeri Zemheri 08 çeşidinde (\% 3.00), en düşük kuru madde değeri ise Kansur çeşidinde (\% 2.33) elde edilmiştir. (Çizelge 4). Olgunlaşma dönemi ve tür interaksiyonu yönünden yapılan değerlendirmeye göre Zemheri 08 çeşidinin kuru madde alım değerine ait ortalamalar tüm olgunlaşma dönemlerinde \% 3.00 olarak hesaplanmıştır. Kansur ve Selçuklu 2002 çeşitlerinin kuru madde alım değeri ortalamaları ise \% 2.00-3.00 arasında hesaplanmıştır (Çizelge 4).

Güzeloğulları ve Albayrak (2016) Isparta ekolojik şartlarında fiğde yaptıkları çalışmada, kuru madde alım değerlerinin farklı ekim ve biçim tarihlerine göre \% 3.07-3.67 arasında değişiklik gösterdiğini bildirmiştir. Bulgularımız araştırıcıların elde ettiği bulgulardan bir miktar düşük çıkmıștır. Bu farklılığın iklim şartları ve çeşit farklılıklarına bağlı olduğu söylenebilir.

\subsection{Nispi Yem Değeri}

Nispi yem değeri, kaba yemlerin tüm değerini tanımlamada kullanılan bir birimdir (Henning ve vd., 2000). Kaba yem kalitesini belirlemede kullanılan NYD tek bir rakamdan oluşmaktadır. Nispi yem değeri ölçüsü otun fiziksel özelliği ve protein değeri hakkında bilgi vermemekte, protein ve fiziksel özellikleri ile birlikte kullanıldı ğında iyi bir ölçü oluşturmaktadır (Ball ve vd., 1996). Hesaplama sonucu elde edilen bu rakam yemin değeri hakkında en iyi bilgiyi vermektedir ve kuru otun kalitesi ile ilişki kurmanın doğru ve etkili bir yoludur (Tremblay, 1998). Araştırmada elde edilen nispi yem değerlerini sınıflandırmada kullanılmak üzere oluşturulan yem kalite standartları Çizelge 5'in altında dipnot olarak verilmiştir (Rivera and Parish, 2010).Türlerin nispi yem değerlerine ait ortalamalar 115.32133.76 arasında değişim göstermektedir (Çizelge 5). En yüksek ortalama nispi yem değeri Zemheri 08 çeşidinde 133.76 , en düşük ortalama nispi

Çizelge 4. Farklı olgunlaşma dönemlerinde biçilen fiğ türlerinin sindirilebilir kuru madde ve kuru madde alım değeri ortalamaları ve oluşan gruplar

$$
\text { Sindirilebilir Kuru Madde Değeri (\%) Kuru Madde Alım Değeri (\%) }
$$

\begin{tabular}{lcccccccc}
\hline & Zemheri 08 & Kansur & Selçuklu & Ort. & Zemheri 08 & Kansur & Selçuklu & Ort. \\
\hline ÇB & 65.66 & 63.00 & 62.33 & $63.67^{\mathrm{A}+}$ & 3.00 & 2.33 & 3.00 & $2.78^{\mathrm{A}+}$ \\
\%50 ÇD & 62.33 & 61.66 & 58.66 & $60.89^{\mathrm{C}}$ & 3.00 & 2.00 & 2.00 & $2.33^{\mathrm{B}}$ \\
& & & & & & & & \\
TÇD & 63.00 & 60.00 & 61.66 & $61.55^{\mathrm{BC}}$ & 3.00 & 2.00 & 3.00 & $2.67^{\mathrm{A}}$ \\
BOD & 66.00 & 63.00 & 60.00 & $63.00^{\mathrm{AB}}$ & 3.00 & 3.00 & 2.33 & $2.78^{\mathrm{A}}$ \\
\hline Ort. & $64.25^{\mathrm{A}^{*}}$ & $61.91^{\mathrm{B}}$ & $60.66^{\mathrm{B}}$ & 62.27 & $3.00^{\mathrm{A}^{*}}$ & $2.33^{\mathrm{C}}$ & $2.58^{\mathrm{B}}$ & 2.63 \\
\hline VK & 2.60 & & & \multicolumn{5}{c}{ VK }
\end{tabular}

$\left.{ }^{\dagger}\right)$ Aynı sütun içerisinde benzer harf ile gösterilen ortalamalar LSD testine göre $\mathrm{P} \leq 0.01$ hata sınırları içerisinde birbirinden istatistiksel olarak farksızdır. *) Aynı satır içerisinde benzer harf ile gösterilen ortalamalar LSD testine göre $\mathrm{P} \leq 0.01$ hata 
Çizelge 5. Farklı olgunlaşma dönemlerinde biçilen fĭg türlerinin nispi yem değeri ortalamaları ve oluşan gruplar

Nispi Yem Değeri ${ }^{1}$

\begin{tabular}{llccc}
\hline & \multicolumn{1}{c}{ Zemheri 08 } & Kansur & Selçuklu & Ort. \\
\hline ÇB & $145.10^{\mathrm{a}}$ & $117.62^{\mathrm{ac}}$ & $138.30^{\mathrm{ac}}$ & $133.68^{\mathrm{A}+}$ \\
$\% 50$ ÇD & $126.18^{\mathrm{ac}}$ & $114.64^{\mathrm{ac}}$ & $100.78^{\mathrm{bc}}$ & $113.87^{\mathrm{C}}$ \\
TÇD & $125.05^{\mathrm{ac}}$ & $98.33^{\mathrm{c}}$ & $124.60^{\mathrm{ac}}$ & $116.00^{\mathrm{C}}$ \\
BOD & $138.69^{\mathrm{ab}}$ & $130.66^{\mathrm{ac}}$ & $111.82^{\mathrm{ac}}$ & $127.06^{\mathrm{B}}$ \\
\hline Ort. & $133.76^{\mathrm{A}^{*}}$ & $115.32^{\mathrm{B}}$ & $118.88^{\mathrm{B}}$ & 122.65 \\
\hline VK & 3.63 & & &
\end{tabular}

${ }^{+}$) Aynı sütun içerisinde benzer harf ile gösterilen ortalamalar LSD testine göre $\mathrm{P} \leq 0.01$ hata sinırları içerisinde birbirinden istatistiksel olarak farksızdır. *) Aynı satır içerisinde benzer harf ile gösterilen ortalamalar LSD testine göre $\mathrm{P} \leq 0.01$ hata sınırları içerisinde birbirinden istatistiksel olarak farksızdır. ")Nispi yem değeri puanlarının anlamı:" 151 'den büyükse "en kaliteli", 151-125 arasında ise "1. sinıf", 124-103 arasında ise "2. sinıf", 102-87 arasında ise "3. sinıf", 86-75 arasında ise "4. sınıf” ve 75'den küçükse "5. sınıf"

yem değeri ise Kansur çeşidinde 115.32 olarak bulunmuştur. Yine olgunlaşma dönemlerine göre nispi yem değerine ait ortalamalar 113.87-133.68 arasında değişmektedir (Çizelge 5). En yükssek ortalama nispi yem değeri çiçeklenme başlangıcı döneminde 133.68, en düşük ortalama nispi yem değeri aynı grupta yer alan \%50 çiçeklenme ve tam çiçeklenme dönemlerinde (sırası ile 113.87 ve 116.00) saptanmıştır (Çizelge 5). Olgunlaşma dönemi ve tür interaksiyonu yönünden yapılan değerlendirmeye göre Zemheri 08 çeşidinin nispi yem değeri ortalamaları 125.05-145.10, Kansur çeşidinin nispi yem değeri ortalamaları 98.33130.66 ve Selçuklu 2002 çeşidinin nispi yem değeri ortalamaları ise 111.82-138.30 arasında belirlenmiştir (Çizelge 5). Nispi yem değeri ile ilgili elde ettiğimiz bulgular, Mutlu (2012)'nun Haymana-İkizce ekolojik koşullarında (83.32) elde ettiği sonuçlardan yükssek çıkmış, Güzeloğulları ve Albayrak (2016)'ın Isparta ekolojik koşullarında (150.5) ve Kavut ve Geren (2018)'in Bornova-İzmir ekolojik koşullarında
(145.00) elde ettiği sonuçlarla benzerlik göstermiştir.

\section{SONUÇLAR}

Farklı olgunlaşma dönemlerinin üç farklı fiğ (Vicia sp.) türünün kuru ot verimi ve kalitesinin incelendiği çalışmadan elde edilen bulgulara dayanarak, Kahramanmaraş şartlarında kuru ot verimi açısından en uygun fiğ türünün Selçuklu 2002 (tüylü fiğ) çeşidi olduğu belirlenmiştir. Yine en uygun biçim zamanının çiçeklenme başlangıcı haricindeki diğer üç farklı olgunlaşma dönemi (\%50 Çiçeklenme Dönemi, Tam Çiçeklenme Dönemi ve Bakla Olum Dönemi) olduğu, ekolojik şartlar ve daha sonra ekilecek bitkiye bağlı olarak bu üç dönemden herhangi birisinin tercih edilebileceği ve bu üç döneme ait ortalamalar arasinda istatistiksel olarak fark bulunmadığ1 görülmüştür. Yine araştırma sonuçlarına göre, Kahramanmaraş şartlarında ham protein verimi yönünden Kansur (macar fiği) ve Selçuklu 2002 (tüylü fiğ) çeşitleri arasında istatistiksel olarak fark olmadığı ve her 
iki çeşidin de tercih edilebileceği bulunmuştur. Ham protein verimi bakımından çiçeklenme başlangıcı haricindeki dönemler arasında herhangi bir fark olmadığı belirlenmiștir. Son olarak nispi yem değeri açısından ele alındığında ise Kahramanmaraş şartlarında en uygun fiğ türünün Zemheri 08 çeşidi (yaygın fiğ) olduğu ve çiçeklenme başlangıcında biçilmesinin uygun olduğu belirlenmiştir.

\section{TEŞEKKÜR}

$\mathrm{Bu}$ çalışma Kahramanmaraş Sütçü İmam Üniversitesi Bilimsel Araştırma Projeleri Koordinasyon Birimi tarafindan finansal olarak desteklenmiştir (Proje Numarası: 2018/3-15 YLS).

\section{NOT}

$\mathrm{Bu}$ makalede araştırma ve yayın etiğine uyulmuştur.

$\mathrm{Bu}$ araştırma için etik kurul izni ve/veya yasal/ özel izin alınmasına gerek duyulmamıştır.

Herhangibir “ÇıkarÇatışması"bulunmamaktadır. Makalede yazarlar eşit oranda katkı sağlamıştır.

\section{KAYNAKLAR}

Akdeniz, H., Keskin B. ve Y1lmaz, B., 1999. Van kıraç şartlarında bazı fiğ türlerinin kışlık olarak yetiştirme olanakları üzerinde bir araştırma, Uluslararası Hayvancılık Kongresi (21-24 Eylül, İzmir) Bildirileri, s. $248-253$.

Aksoy, İ. ve Nursoy, H., 2010. Vejetasyonun farklı dönemlerinde biçilen macar fiği buğday karışımının besin madde kompozisyonu, rumende y1kılım özellikleri, in vitro sindirilebilirlik ve rölatif yem değerinin belirlenmesi. Kafkas Üniv. Vet. Fak. Derg., 16(6): 925-931.

Albayrak, S., Türk, M. ve Yüksel, O., 2009. Effects of phosphorus fertilization and harvesting stages on forage yield and quality of wool pod vetch. Turkish Journal of Field Crops, 14(1): 30-40.

Anonim, 2018a. Kahramanmaraş Meteoroloji İl Müdürlüğü Verileri. Kahramanmaraş.

Anonim, 2018b. KSÜ ÜSKİM Toprak Analiz Sonuçları, Kahramanmaraş.

Anonim, 2019b. Nitrogen Determination by Kjeldahl Method. https://www. itwreagents.-com/uploads/20180114/ A173 EN.pdf

Bağcı, M., 2010. Orta anadolu koşullarında macar fiğinde (Vicia pannonica Crantz cv. Tarmbeyaz1-98) sira arası ve tohum miktarının ot verimine etkileri. Yüksek Lisans Tezi. Çukurova Üniversitesi, Fen Bilimleri Enstitüsü, Tarla Bitkileri Anabilim Dalı, Adana.

Ball, D.M., Hovelend, C.S. and Lacefield, G.D., 1996. Forage Quality in Southern Forages. Potash \& Phosphate Institute. Norcross, Georgia, s. 124-132.

Budak, F. ve Budak, F., 2014. Yem Bitkilerinde Kalite ve Yem Bitkileri Kalitesini Etkileyen Faktörler. Türk Bilimsel Derlemeler Dergisi, 7 (1): 01-06.

Budak, F., Büyükburç, U. ve Budak, H., 1997. Kayseri ekolojik koşullarında farklı ekim zamanlarının bazı fiğ (Vicia spp.) türlerinin tarımsal özelliklerine etkisi. Türkiye 2 . Tarla Bitkileri Kongresi (22-25 Eylül, 
Samsun) Bildirileri. s. 696-698.

Canpolat, Ö ve Karaman, Ş., 2009 Bazı baklagil

kaba yemlerinin in vitro gaz üretimi, organik madde sindirimi, nispi yem değeri ve metabolik enerji içeriklerinin karşılaştırılması. Tarım Bilimleri Dergisi, 15(2): 188-195.

Cassida, K. A., Griffin, T. S., Rodriguez, J., Patching, S. C. Hesterman, O. B. and Rust, S. R., 2000. Protein Degradability and Forage Quality in Maturing Alfalfa, Red Clover and Birdsfoot Trefoil. Crop Science. 40: 209-215

Çaçan, E., Kökten, E., Kaplan, M. ve Y1lmaz, H.Ş., 2017. Bazı adi fiğ hat ve çeşitlerinin (Vicia sativa L.) ot verimi ve ot kalitesi açısından değerlendirilmesi. Harran Tarım ve Gida Bilimleri Dergisi, 22(1): 47-61.

Dündar, F.Ç., 2010. Yazlık ekilen bazı yaygın fiğ çeşitlerinin verim ve verim unsurlarının belirlenmesi. Yüksek Lisans Tezi. Namık Kemal Üniversitesi, Fen Bilimleri Enstitüsü, Tekirdağ.

Erdoğdu, İ., Sever, A. ve Atalay, A., 2016. Eskişehir koşullarında macar fiği (Vicia pannonica Crantz.) hat ve çeşitlerinde yem ve tohum verimleri. Tarla Bitkileri Merkez Araştırma Enstitüsü Dergisi, 25(2): 230234.

Güzeloğulları, E. ve Albayrak, S., 2016. Isparta ekolojik koşullarında farklı ekim ve hasat zamanlarının bazı fiğ (Vicia spp.) türlerinin ot verim ve kalitesi üzerine etkileri. Tarla Bitkileri Merkez Araştırma Enstitüsü Dergisi, 25(2): 158-165.

Hashalıc1, S., Uzun, S., Özaktan, H. ve Kaplan, M., 2017. Kayseri kıraç koşullarında yetiştirilen bazı macar fiği çeşitlerinin ot verimleri ve kalitelerinin belirlenmesi. Erciyes Üniversitesi Veteriner Fakültesi Dergisi, 14(2): 113-123.

Henning, J.C., Lacefield, G.D. and Amaralphilips, D., 2000. Interpreting Forage Quality Reports Cooperative Extension Service. ID-101.

Kaçar, B., 1972. Bitki ve Toprağın Kimyasal Analizleri: II. Bitki Analizleri. Ankara Üniversitesi Basımevi, Ankara, 646s.

Kaplan, M., 2013. Yaygın fiğ (Vicia sativa L.) genotiplerinde hasat zamanının ot verim ve kalitesine etkisi. Erciyes Üniversitesi, Fen Bilimleri Enstitüsü Dergisi, 29(1): 7680.

Kara, İ., 2013. Farklı dönemlerde hasat edilen adi fiğ macar fiği ve yem bezelyesinde ot verimi ve kalitesinin değişimi. Yüksek Lisans Tezi. Atatürk Üniversitesi, Fen Bilimleri Enstitüsü, Erzurum.

Kavut, Y., Geren, H., 2018. İtalyan çimi (Lolium multiflorum L.) + tüylü fiğ (Vicia villosa L.) karışımlarında farklı hasat zamanları ve karışım oranlarının verim ve kalite özelliklerine etkisi, Mediterranean Agricultural Sciences, 31(3): 283-287.

Kavut, Y.T., Geren, H., Soya, H., Avcioğlu, R. ve Kır, B., 2014. Karışım Oranı ve Hasat Zamanlarının Bazı Yıllık Baklagil Yembitkileriile İtalyan Çimi Karışımlarının Kışlık Ara Ürün Performansına Etkileri. Ege Üniv. Ziraat Fak. Derg., 51(3): 279288.

Kuşvuran, A., Kaplan, M. ve Nazli, R.İ., 2014. Effects of mixture ratio and row spacing in hungarian vetch (Vicia pannonica Crantz.) 
and annual ryegrass (Lolium multiflorum Lam.) intercropping system on yield and quality under semiarid climate conditions. Turkish Journal of Field Crops, 19(1): 118128.

Kutlu, H.R., 2008. Yem Değerlendirme ve Analiz Yöntemleri. Ç.Ü. Ziraat Fak. Zootekni Bölümü, Ders Notu, Adana, 65s.

Morrison, J.M., 1998. Changes in the lignin and hemicellulose concentration of ten varieties of temperate grasses with increasing maturity. Grass legumes for forage production in mild winter areas. Grass and Forage Sci., 53:318-325.

Mutlu, Z., 2012. Bazı kışlık fiğ türlerinde biçim zamanının ot verimine etkisi. Yüksek Lisans Tezi. Ankara Üniversitesi, Fen Bilimleri Enstitüsü, Ankara.

Özen H. Ç. ve Onay, A., 1999. Bitki Büyüme ve Gelişme Fizyolojisi. Dicle Üniversitesi Basımevi. Diyarbakır, $166 \mathrm{~s}$.

Parlak, A.Ö., 2005. Bazı yapay mera karışımlarında ekim yöntemleri ve azot dozlarının yem verimi ve kalitesine etkileri. Doktora Tezi. Ankara Üniversitesi, Fen Bilimleri Enstitüsü, Ankara. 188s.

Rebole, A., Alzueta, C., Ortiz, L.T., Baro, C., Rodriguez, M.L and Caballero, R., 2004. Yield and chemical composition of different parts of the common vetch at flowering and two seed filling stage. Spanish J. Agric. Res., 2(4): 550-557.

Rivera, D., and Parish, J., 2010. Interpreting Forage and Feed Analysis Report. 2620, Mississippi State University.

Sarıçiçek, Z., Garipoğlu, A. ve Sarıcan, C., 1996. Adi Fiğ ve Macar Fiğinin Yem Değeri
Üzerine Bir Araştırma. Ondokuz Mayıs Üniversitesi Ziraat Fakültesi Dergisi. 11(2): 39-45.

SAS, 2013. SAS V.9.3 User Guide, Copyright (C) 2013, SAS Institute Inc., Cary, NC, USA. Sheaffer, C.C., Peterson, M.A., Mccalin, M., Volene, J.J, Cherney, J.H, Johnson, K.D., Woodward, W.T. and Viands, D.R., 1995. Acid Detergent Fibre, Neutral Detergent Fibre Concentration and Relative Feed Value. North American Alfalfa Improvement Conference, Minneapolis.

Sürmen, N., Yavuz, T. ve Çankaya, N., 2011. Effects of phosphorus fertilization and harvesting stage on forage yield and quality of common vetch. Journal of Food, Agriculture \& Environment, 9(1): 353355.

Tremblay, M., 1998. A Tool for Determining Alfalfa Quality. Saskatchewan Agriculture and Food. Saskatchewan.

Turna, Ç., Ertuş, M., 2017. Bazı fiğ çeşitlerinde farklı ekim zamanlarının ot verimine etkisi.

3. Uluslararası Tarım ve Çevre Kongresi Bildiriler Kitab1, Antalya, s. 132-138.

Türk, M., Albayrak, S. ve Yüksel, O., 2009. Effects of fertilisation and harvesting stages on forage yield and quality of hairy vetch (Vicia villosa Roth.). New Zealand Journal of Agricultural Research, 52: 269275 .

Ünal, S., Mutlu, Z. and Fırıncığlu, H.K., 2011. Performances of some winter hungarian vetch accessions (Vicia pannonica Crantz.) on the highlands of turkey. Turkısh Journal of Field Crops, 16(1); 1-8.

Van Soest, P.J., 1994. Nutritional ecology of 
ruminants, 2nd ed. Cornel University Pres, pp. 476.

Wilson, J.R., Deinum, H., Engels, E.M., 1991. Temperature effects on anatomy and digestibility of leaf and stem of tropical and temperate forage species. Neth. J. Agric Sci., 39: 31-48.

Yılmaz, Ş., Günel, E. ve Sağlamtimur, T., 1996. Amik ovası ekolojik koşullarında yetiştirilebilecek uygun fĭg (Vicia spp.) türlerinin saptanması üzerinde bir araştırma. Türkiye 3. Çayır-Mera ve Yem Bitkileri Kongresi (17-19 Haziran, Erzurum) Bildirileri, s. 627-631. 